\title{
Quantifying pyroconvective injection heights using observations of fire energy: sensitivity of spaceborne observations of carbon monoxide
}

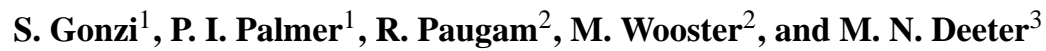 \\ ${ }^{1}$ School of GeoSciences, University of Edinburgh, Edinburgh, UK \\ ${ }^{2}$ Department of Geography, King's College London, London, UK \\ ${ }^{3}$ National Center for Atmospheric Research NCAR, Boulder, CO, USA \\ Correspondence to: S. Gonzi (sgonzi@ @staffmail.ed.ac.uk)
}

Received: 31 July 2014 - Published in Atmos. Chem. Phys. Discuss.: 3 September 2014

Revised: 27 January 2015 - Accepted: 12 February 2015 - Published: 29 April 2015

\begin{abstract}
We use observations of active fire area and fire radiative power (FRP) from the NASA Moderate Resolution Imaging Spectroradiometers (MODIS), together with a parameterized plume rise model, to estimate biomass burning injection heights during 2006. We use these injection heights in the GEOS-Chem (Goddard Earth Observing System Chemistry) atmospheric chemistry transport model to vertically distribute biomass burning emissions of carbon monoxide (CO) and to study the resulting atmospheric distribution. For 2006, we use over half a million FRP and fire area observations as input to the plume rise model. We find that convective heat fluxes and active fire area typically lie in the range of $1-100 \mathrm{~kW} \mathrm{~m}^{-2}$ and $0.001-100 \mathrm{ha}$, respectively, although in rare circumstances the convective heat flux can exceed $500 \mathrm{~kW} \mathrm{~m}^{-2}$. The resulting injection heights have a skewed probability distribution with approximately $80 \%$ of the injections remaining within the local boundary layer (BL), with occasional injection height exceeding $8 \mathrm{~km}$. We do not find a strong correlation between the FRPinferred surface convective heat flux and the resulting injection height, with environmental conditions often acting as a barrier to rapid vertical mixing even where the convective heat flux and active fire area are large. We also do not find a robust relationship between the underlying burnt vegetation type and the injection height. We find that $\mathrm{CO}$ columns calculated using the MODIS-inferred injection height (MODISINJ) are typically -9 to $+6 \%$ different to the control calculation in which emissions are emitted into the BL, with differences typically largest over the point of emission. After applying MOPITT (Measurement of Pollution in the Tropo-
\end{abstract}

sphere) v5 scene-dependent averaging kernels we find that we are much less sensitive to our choice of injection height profile. The differences between the MOPITT and the model $\mathrm{CO}$ columns $(\max$ bias $\approx 50 \%$ ), due largely to uncertainties in emission inventories, are much larger than those introduced by the injection heights. We show that including a realistic diurnal variation in FRP (peaking in the afternoon) or accounting for subgrid-scale emission errors does not alter our main conclusions. Finally, we use a Bayesian maximum a posteriori approach constrained by MOPITT CO profiles to estimate the $\mathrm{CO}$ emissions but because of the inherent bias between model and MOPITT we find little impact on the resulting emission estimates. Studying the role of pyroconvection in the distribution of gases and particles in the atmosphere using global MOPITT CO observations (or any current spaceborne measurement of the atmosphere) is still associated with large errors, with the exception of a small subset of large fires and favourable environmental conditions, which will consequently lead to a bias in any analysis on a global scale.

\section{Introduction}

Fire plays an important role in the evolution of the Earth system (Bowman et al., 2009). We focus on the influence of fires on determining the atmospheric distribution of carbon monoxide (CO), a chemical tracer of incomplete combustion. In particular, we use spaceborne measurements of fire radiative power (FRP) and estimates of the fire active fire 
area over which this radiative output is produced, to describe the enhanced vertical mixing due to intense surface heating to (a) understand the resulting atmospheric variation in $\mathrm{CO}$, and (b) quantify the impact on surface flux estimates inferred from atmospheric measurements of $\mathrm{CO}$.

Satellite observations have played a central role in understanding the spatial extent and seasonality of fires across different ecosystems (e.g. Cahoon Jr. et al., 1992; Barbosa et al., 1999; Carmona-Moreno et al., 2005; Csiszar et al., 2006; van der Werf et al., 2006; Giglio, 2007; Boschetti et al., 2010; Ichoku et al., 2012). There is a substantial body of previous work on estimating biomass burning emissions of gases and particles using spaceborne instruments with varying levels of success (e.g. Duncan et al., 2003; Martin et al., 2003; Ito and Penner, 2004; Kasischke and Penner, 2004; Freitas et al., 2005; Edwards et al., 2006; Hodzic et al., 2007; Jordan et al., 2008; Kopacz et al., 2009; Liousse et al., 2010; Gonzi et al., 2011b; Fleming et al., 2012; Ross et al., 2013), largely reflecting heterogeneous sampling due to cloud- and aerosol-contaminated observed scenes.

Recent works have studied how injection heights can modify emitted gases and aerosols and downwind chemical composition (e.g. Palmer et al., 2013, and articles therein). Strictly speaking, pure pyroconvection is rare, with most events triggered by storm systems that can result in unstable atmospheric conditions and enhance the vertical extent of the mixing due to the fire (e.g. Dirksen et al., 2009; Fromm et al., 2010). The importance of vertical mixing due to some extent by surface heating from fire has been shown by a number of previous studies that have used models with and without a description of pyroconvection to interpret aircraft and satellite data (e.g. Freitas et al., 2010; Fisher et al., 2010; Sessions et al., 2011; Zhang et al., 2011; Pfister et al., 2011). Within these studies, pyroconvection is typically treated in an ad hoc manner using a formulaic method of vertically redistributing surface emissions (e.g. Val Martin et al., 2012). The uncertain nature and availability of input parameters and their relation to the prognostic model description often prohibits a better method for redistributing mass. FRP has been shown in small-scale experiments to be related to rates of fuel combustion Wooster et al. (2005) and to rates of key trace gas and aerosol emission Freeborn et al. (2008). At the landscape scale, previous work has shown that MODIS (Moderate Resolution Imaging Spectroradiometers) FRP measurements were related to the release rate of smoke aerosols Ichoku and Kaufman (2005); Vermote et al. (2009) and, recently, MODIS FRP has been used to map daily landscapescale fuel consumption rates Kaiser et al. (2012) and, via the application of biome-specific emission factors, the rates of release of various chemical species present in the smoke.

In the following section, we describe the FRP and active fire area estimates derived from the MODIS measurements and the CO data from the MOPITT (Measurement of Pollution in the Troposphere) satellite instrument. In Sect. 3 we describe the plume rise model and how we incorporate the resulting injection height inferred from the MODIS data into the GEOS-Chem (Goddard Earth Observing System Chemistry) atmospheric chemistry transport model. In Sect. 4, we report our results. We conclude in Sect. 5.

\section{Data}

\subsection{MODIS fire observations}

To calculate active fire properties we use data collected by the MODIS instruments on the Aqua and Terra satellites Wooster et al. (2005); Ichoku et al. (2008). Both satellites are in sun-synchronous, near-polar orbits. Terra and Aqua have an equator crossing local solar time of 10:30 a.m. (10:30 p.m.) and 01:30 a.m. (01:30 p.m.) for their descending (ascending) nodes, respectively.

MODIS pixels containing active fires are selected using the MOD14/MYD14 active fire masks Giglio et al. (2003) or the Sentinel-3 SLSTR (Sea and Land Surface Temperature Radiometer) active fire detection algorithm Wooster et al. (2012). Detected active fire pixels immediately neighbouring one another are then grouped into discrete fire clusters, which is the same approach as previously applied to data from the BIRD (Bi-spectral IR Detection) Hot spot Recognition Sensor Wooster et al. (2003); Zhukov et al. (2005). The middle infrared (MIR) and long-wave infrared (LWIR) radiance data are adjusted for the transmittance of the atmosphere in order to better estimate the fire-emitted radiances. The atmospheric transmittances are estimated from precompiled lookup tables derived from MODTRAN runs and based on the total column water vapour $\left(\mathrm{kg} \mathrm{m}^{-2}\right)$ (taken from ECMWF reanalysis) and the sensor view zenith angle Govaerts et al. (2010). The FRP of the active fire pixels that comprise each fire cluster are computed from the MODIS MIR band radiances using the MIR method of Wooster et al. (2005) and the FRP for each fire cluster obtained by simple summation of the individual pixel-level values. The active fire (AF) area (calculated as the area of a blackbody having the same thermal emission signatures in the MIR and LWIR as does the observed active fire) was computed using the dual-band/bispectral approach of Dozier (1981), with the specific method of Zhukov et al. (2005) applied to the mean MIR and LWIR radiances of each fire cluster. A similar approach was already used by previous studies Val Martin et al. (2012); Peterson et al. (2013), and calculating the $\mathrm{AF}$ area on a cluster basis rather than on a perpixel basis helps to minimize some of the problems of the dual-band method, especially those related to interchannel spatial misregistration effects Shephard and Edward (2003); Zhukov et al. (2005); Giglio and Schroeder (2014).

Figure 1 shows the MODIS-derived distribution of half a million co-located FRP and active fire area data during 2006. The measurement density is highest over equatorial regions, with higher latitudes having fewer observations that reflect their seasonal cycle. 

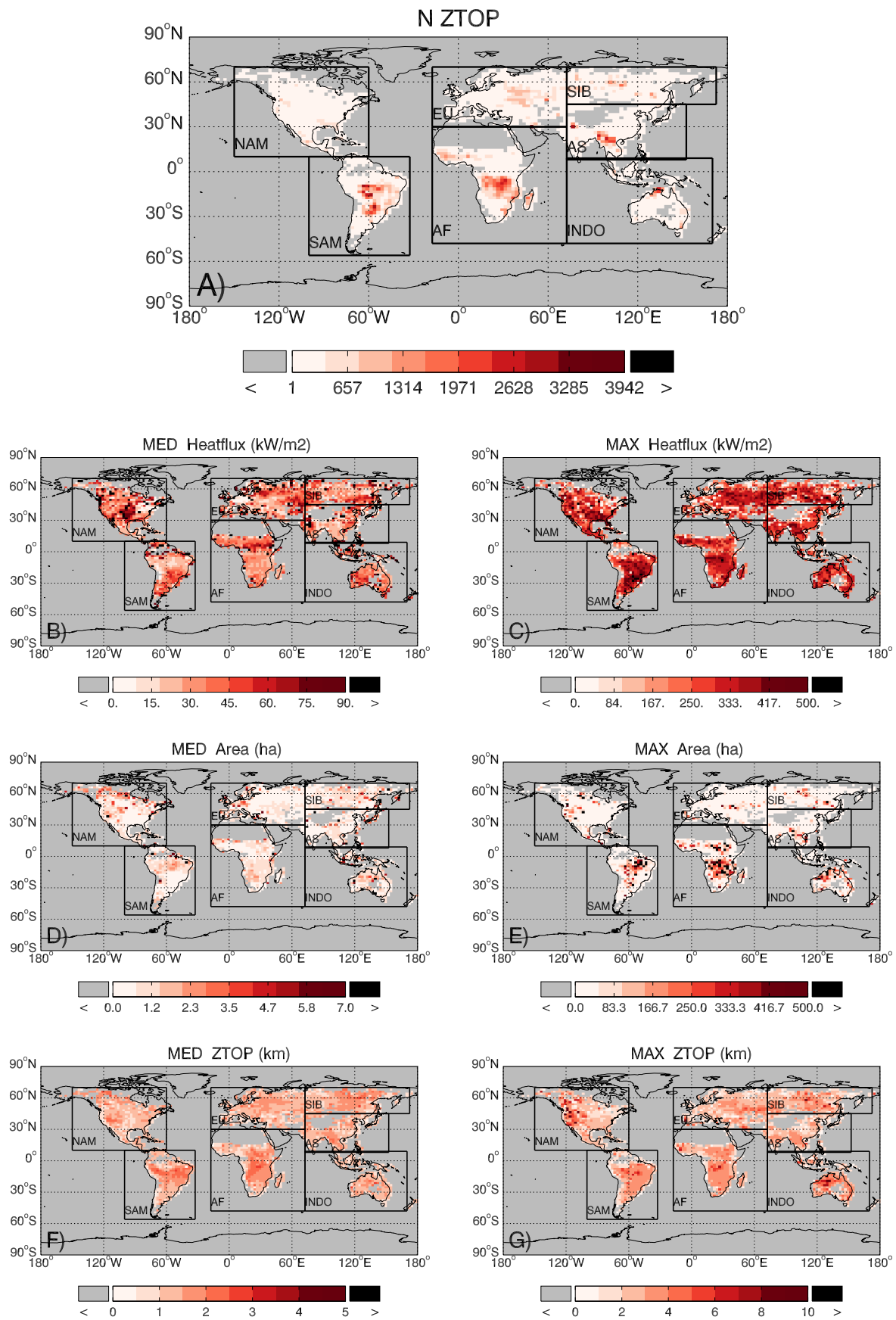

Figure 1. (a) Spatial distribution of the number of MODIS observations that fall into $2.0^{\circ} \times 2.5^{\circ}$ GEOS-Chem grid boxes during 2006, and the median (MED) and maximum values (MAX) for (b) and (c) radiant heat flux $\left(\mathrm{kW} \mathrm{m}^{-2}\right)$, (d) and (e) active fire area (ha), and (f) and (g) the resulting injection height ZTOP $(\mathrm{km})$. The study regions include North America (NAM), South America (SAM), Europe (EU), Africa (AF), Siberia (SIB), Asia (AS), and Indonesia (INDO).

\subsection{Relation between FRP and heat flux}

Here, we use flux estimates inferred from FRP observations, assuming an underlying relationship between the two variables. Fire energy can broadly speaking be separated into three components: conduction, radiation and convection. The individual contributions from these sources to the total fire energy is uncertain, but it can be assumed that convection is as important as radiative energy Anderson et al. (2010); Butler (2010); Finney et al. (2012); Frankman et al. (2012). The maximum radiative heat yield that is typically measured by MODIS is about $20 \%$ Wooster et al. (2005) of the total 
heat, whereas the maximum heat yield that can theoretically be liberated by a fire is between 20 and $60 \%$ Ferguson et al. (2000). We assume that heat loss by conduction is relatively small compared to losses by the combined effect of radiation and convection. We assume an average heat loss of $15 \%$ for radiation, $10 \%$ for conduction, and $75 \%$ due to convection $\left(\mathrm{HF}, \mathrm{kW} \mathrm{m}^{-2}\right.$ ). The loss by convection is then given as $\mathrm{HF}=5 \times \frac{\mathrm{FRP}}{\mathrm{AF}}$, where $\mathrm{AF}\left(\mathrm{m}^{2}\right)$ denotes the active fire area. We acknowledge here that this relation is probably the upper limit and will not hold true for every location and fire type around the globe, but it is a reasonable mean estimate based on current knowledge.

\subsection{MOPITT profile observations of $\mathrm{CO}$}

We use MOPITT v5 CO profile retrievals and the corresponding retrieval error covariances and scene-dependent averaging kernels for 2006 Deeter (2011). CO concentrations are retrieved for 10 pressure levels (surface, 900, 800,..., $100 \mathrm{hPa}$ ) in the multispectral thermal-IR/near-IR (TIR/NIR) regions based on log-normal statistics and an optimal estimation method. We do not consider the TIR- and NIR-only products here. The a priori CO information in the MOPITT retrieval algorithm is calculated with the global chemistry transport model MOZART Horowitz et al. (2003), and meteorology in the retrieval algorithm is based on NCEP reanalysis data Kalnay et al. (1996). A typical value for the degrees of freedom (DOF) of a single CO profile, based on the combined TIR/NIR retrieval scheme, is between 1.0 and 2.2. In comparison, the DOFs for the NIR- and TIR-only products range from 0.1 to 1.0 and from 0.5 to 1.5 , respectively Deeter et al. (2012).

Past analyses showed that these MOPITT $\mathrm{CO}$ profiles have a bias when compared against North American in situ tall-tower measurements (2000-2011) of typically $-20 \%$ to $+20 \%$ with a pronounced seasonal cycle Deeter et al. (2013). To facilitate ease of analysis we thin the MOPITT data and use a maximum of three observations in a $1^{\circ} \times 1^{\circ}$ grid cell for each day. We use the first three profiles in a given time step that satisfy the following criteria: (a) DOF $>1.3$, and (b) $\mathrm{CO}$ profile concentrations at the $500 \mathrm{hPa}$ pressure level > $40 \mathrm{ppb}$ Gonzi et al. (2011a). This reduces the number of profiles considerably to approximately 5 million observations during 2006. We find that using a more relaxed DOF criterion (DOF $>0.8$ ), allowing for more observations $(N=30)$ to be collected per grid box, does not significantly affect our final analysis (see Figs. 8 and 11).

\section{Models}

\subsection{Plume rise model}

Pyroconvection is currently a subgrid-scale model process; resolving this process in a global model would involve prohibitive computational costs. Consequently, models tend to parameterize this process if they include it at all. We use an established 1-D plume rise model (Freitas et al., 2006, 2010), embedded within the GEOS-Chem atmospheric chemistry transport model, described below, to describe the vertical mixing due to surface heating and consequently to redistribute surface emissions from the fire. The plume rise model estimates the injection height, defined as the level of neutral buoyancy, by solving equations for the vertical plume velocity, plume temperature, condensation and evaporation (latent heat), accounting for wind shear. We use a parameterization to conserve mass (Appendix A), which is an extension to the original code first published by Freitas et al. (2006).

Initial surface boundary conditions in the plume rise model include MODIS-derived convective heat flux $\left(\mathrm{kW} \mathrm{m}^{-2}\right.$, defined above) and active fire area $\left(\mathrm{m}^{2}\right)$, respectively, environmental temperature $(\mathrm{K})$, relative humidity profile $(\%)$ and horizonal wind fields $\left(\mathrm{m} \mathrm{s}^{-1}\right)$. We drive the plume model using meteorological data from version 5 of the NASA GEOS5 Rienecker et al. (2008), ensuring consistency with the GEOS-Chem meteorology. For each MODIS-derived heat flux and active fire area, an injection height value is calculated by the plume rise model. The role of atmospheric water vapour versus water released from fuel combustion is still subject to debate (e.g. Penner et al., 1986; Potter, 2005; Trentmann et al., 2006; Luderer et al., 2009; Cunningham and Reeder, 2009). We assume a fuel moisture of $10 \%$, which we add to the existing atmospheric levels of calculated co-located GEOS-5 relative humidity profiles (see Appendix Eq. A2). We further assume that the initial plume temperature equals the environmental temperature. The biggest source of moisture variation is from the atmosphere, which is updated with each time step during the fire as the plume temperature changes. Estimates of convective heat flux are also uncertain.

\subsection{The GEOS-Chem atmospheric chemistry model}

We use GEOS-Chem version 9-01-01 (www.geos-chem.org) as the forward model that relates surface emissions of $\mathrm{CO}$ to atmospheric concentrations of $\mathrm{CO}$. The model is driven by meteorological analyses from the Goddard Earth Observing System v5 model maintained by the Global Modeling and Assimilation Office at NASA, Goddard. We use a horizontal resolution of $2^{\circ} \times 2.5^{\circ}$ with $47 \sigma$ levels that span from the surface to $0.01 \mathrm{hPa}$ of which 30 levels are within the troposphere. The 3-D meteorological data are updated every $6 \mathrm{~h}$, and heights of the BL (boundary layer) and tropopause are updated every $3 \mathrm{~h}$.

We use monthly mean emission inventories for fossil fuel Olivier and Berdowski (2001); Streets et al. (2006), biofuel Yevich and Logan (2003), biomass burning van der Werf et al. (2010), and from the oxidation of volatile organic compounds Duncan et al. (2007). Atmospheric oxidation by $\mathrm{OH}$ is the main atmospheric loss of $\mathrm{CO}$, resulting in a lifetime of weeks to months depending on latitude and season. We use monthly 3-D fields of the $\mathrm{OH}$ sink precomputed from a 


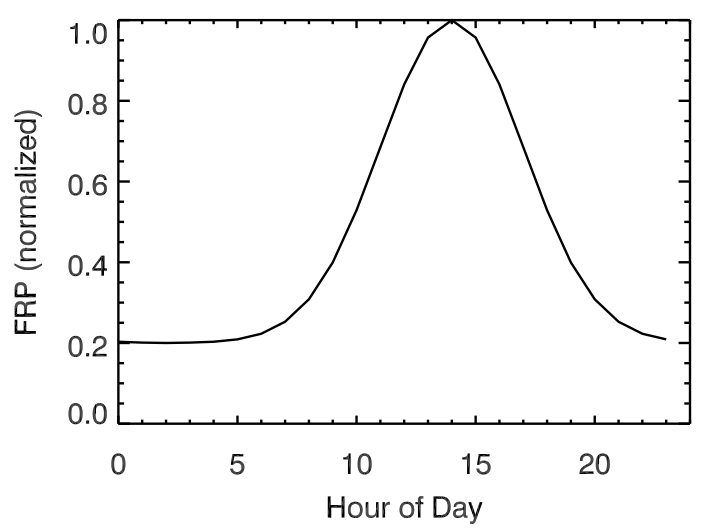

Figure 2. Daily normalized FRP diurnal cycle used in this study.

full chemistry version of the model. Fixing the $\mathrm{OH}$ sink effectively allows us to linearly decompose the contributions of $\mathrm{CO}$ from source types and/or geographical regions. Figure 1 shows the eight geographical regions we study, reflecting the location of burning. For each region we track emissions from biomass burning and combined emissions from fossil fuel and biofuel combustion. We also track the combined contribution of $\mathrm{CO}$ from the oxidation of methane, isoprene, monoterpenes, methanol, and acetone. A more detailed description of this model can be found elsewhere Duncan et al. (2007); Gonzi et al. (2011a). We sample the model at the time and location of MODIS and MOPITT measurements. Below, where we discuss model bias, we define percentage bias as

bias $=100 \times \frac{\mathrm{CO}_{\mathrm{M}}-\mathrm{CO}_{\mathrm{X}}}{\max \left(\mathrm{CO}_{\mathrm{M}}, \mathrm{CO}_{\mathrm{X}}\right)}$,

where $\mathrm{CO}_{\mathrm{M}}$ denotes the model and $\mathrm{CO}_{\mathrm{X}}$ denotes either the sensitivity model run $\mathrm{CO}_{S}$ or the observed atmospheric measurement $\mathrm{CO}_{\mathrm{O}}$.

For the control model run (and the default setting of GEOS-Chem) we distribute biomass burning emissions within the BL, which is described approximately by $15 \mathrm{lev}$ els from the surface to $2.5 \mathrm{~km}$. We take care to conserve mass and each model level within the BL receives the same fractional amount of emission. For the sensitivity runs using FRP to define the injection height we distribute surface emissions in the atmosphere using the plume rise model described above, driven by GEOS-5 meteorological analyses Rienecker et al. (2008). The MODIS-derived FRP data that fall into a specific model grid box during a $3 \mathrm{~h}$ window, determined by the GEOS- 5 analyses, determine the surface convective heat flux boundary conditions. In the typical case of more than one FRP observation falling in a grid square during this time window, we create an injection height profile for each associated convective heat flux: equally distributing emitted mass from the surface to the injection height or from the local BL to the injection height whenever the injection height is larger than the BL. We then calculate an effective injection height by calculating a sum of individual profiles weighted by their respective fractional active fire area burnt within that grid box. This fractional scaling ensures that the final effective profile conserves mass. Note that while emissions are distributed uniformly this approach will not always result in a uniformly scaled profile, at least not for the example case where there are two profiles in a grid box with one having an injection height in the $\mathrm{BL}$ and the other one in the free troposphere. We discuss in Sect. 4.3 the sensitivity of injection height profiles by using a parabolic distribution method. If there are no FRP observations in a model grid box for a particular time but emissions are non-zero we distribute emissions within the local BL.

We also consider the sensitivity of our results to imposing a diurnal cycle on FRP, following analysis of similar data as a function of land cover type over Africa using the Spinning Enhanced Visible and Infrared Imager (SEVIRI) Roberts et al. (2009). Figure 2 shows that the mean diurnal cycle peaks during early afternoon, consistent with previous analysis of data from the GOES WFABBA (Geostationary Operational Environment Satellite Wildfire Automated Biomass Burning Algorithm) active fire observations that show early afternoon peaks valid for the entire globe $\mathrm{Mu}$ et al. (2011); Giglio (2007). We use this mean diurnal profile to relate observations taken at discrete times to the rest of the day, acknowledging this is a crude but reasonable assumption.

\subsection{The maximum a posteriori (MAP) inverse model}

We briefly describe our inverse model approach here, which has also been discussed at length elsewhere Gonzi et al. (2011a). We sample the model along the MOPITT orbit by applying scene-dependent averaging kernels from MOPITT and follow an optimal estimation method in order to fit the model 3-D CO concentrations to the observations.

We apply MOPITT averaging kernels and use the following relation Gonzi et al. (2011a):

$y_{\mathrm{M}}^{\prime}=y_{\mathrm{a}}+\mathbf{A}\left(y_{\mathrm{M}}-y_{\mathrm{a}}\right)$,

where $y_{M}$ is the GEOS-Chem model profile in model space interpolated onto the vertical MOPITT pressure grid, $y_{\mathrm{a}}$ denotes the a priori profile from MOPITT in MOPITT space, $\mathbf{A}$ is the MOPITT averaging kernel matrix (the sum of the diagonal is the degree of freedom, DOF), and $y_{M}^{\prime}$ is the model profile in MOPITT space. The profile concentrations and averaging kernels are in log-space.

Figure 1 shows the eight geographical regions for which we estimate CO emissions: North America (NAM), EU (Europe), SIB (Siberia), INDO (Indonesia), AF (Africa), SAM (South America), AS (Asia) and CHEM (rest of the world including chemistry). We estimate lumped emissions from biomass burning, fossil fuel and biofuel emissions on a quarterly basis (JFM, AMJ, JAS, and OND). We assume a priori uncertainties of $50 \%$ for incomplete combustion emissions and of $25 \%$ for the chemical oxidation source, following 

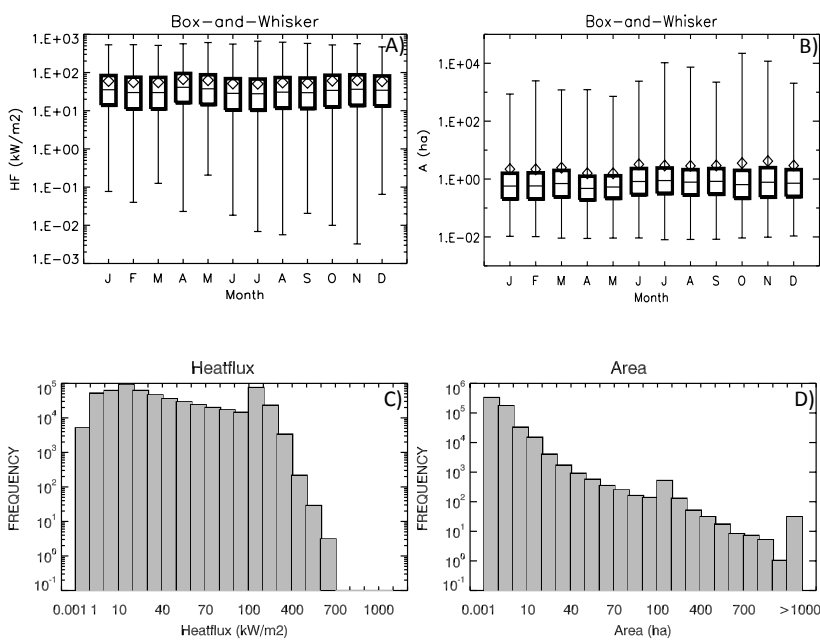

Figure 3. Box-and-whisker plots, (a) and (b), and frequency distributions, (c) and (d), of convective heat flux (HF; $\mathrm{kW} \mathrm{m}^{-2}$ ) and active fire area $A$ (hectare) for the year 2006. For the box-and-whisker plots the mean is denoted by the diamond and the median by a horizontal line within the box. The frequency distribution uses a logarithmic scale for heat flux and active fire area. The $x$ axis denotes the following bins: $0.001,1,5,10,20,30,40,50,60,70,80,90$, $100,200,300,400,500,600,700,800,900$, and 1000-20000. The number of observations reported is approximately 562000 .

previous work Gonzi and Palmer (2010). For measurement errors, we include the local scene-dependent retrieval error from MOPITT to the final total error in log-space. We also include a $25 \%$ uncertainty associated with the combined forward model and representation errors. The MAP algorithm described in a log-measurement space typically converges after a few iterations Gonzi et al. (2011b).

\section{Results}

\subsection{Convective heat fluxes, active fire area, and injection heights for 2006}

Figure 1 shows for 2006 the annual mean values for convection heat flux $\left(\mathrm{kW} \mathrm{m}^{-2}\right)$ inferred from MODIS FRP measurements and the corresponding active fire areas (hectares) used to determine the local pyroconvection injection height. The geographical variation of measurements available to calculate injection height reflects the frequency of fires and the magnitude of associated FRP-derived heat flux, which is related to the fire regime of an area, and to the intensity of the energy emission from those fires. In general, the mean (not shown) and median values of the fire products are similar, suggesting there is little skewness in the distribution of FRP, although we acknowledge that the highest values are typically a factor of 5-10 higher than the mean value and that the median is in general the more robust statistic for this parameter. Figure 3 shows the corresponding global monthly box-and-whisker plots for convective heat flux and active fire area, respectively. The bulk of convective heat flux values are typically in the range $1-100 \mathrm{~kW} \mathrm{~m}^{-2}$ and active fire areas typically lie in the range $0.1-10 \mathrm{ka}$. On occasion, active fire area estimates can exceed $500 \mathrm{ka}$ but these represent only a small percentage of the data.

Figure 1 shows the corresponding injection heights determined by the plume rise model. These data show that the FRP-derived estimates of convective heat flux and active fire area are insufficient by themselves to determine the injection height. This disagrees with field experiment data Lavoué et al. (2000); however, these were small-scale experiments with final injection heights that did not consider atmospheric stability constraints.

\subsection{Sensitivity of injection heights to environmental parameters}

Figure 4 shows two examples where values for MODIS FRP and/or active fire area are similar, but the analysed meteorology for atmospheric temperature and specific humidity are different, resulting in different injection heights. Figure $4 \mathrm{a}$ and $\mathrm{b}$ show two instances where HF and AF have similar values but the lower injection height $(0.1 \mathrm{~km}$ vs. $3.3 \mathrm{~km})$ is associated with a more stable atmosphere as determined by the positive gradient in potential temperature and higher specific humidity. This serves as an example where even modest changes in potential temperature can result in large changes to the model injection height. Figure $4 \mathrm{c}$ and d show a contrasting example where there is clearly a positive gradient in potential temperature, indicative of a stable, stratified atmosphere, but the injection heights are much larger than the corresponding local BL heights. For these two cases, values of $\mathrm{HF}$ and AF are very large with the only difference being that the higher injection height $(10 \mathrm{~km}$ vs. $6.9 \mathrm{~km})$ has almost twice the HF. These two examples highlight the two limits that determine injection height: (1) small fires that rely on unstable environmental conditions to penetrate the free troposphere, and (2) large fires (defined here as having high FRP and large active fire area) that can overcome locally stable environmental conditions to penetrate into the free troposphere. There are of course a continuum of possible combinations of variables between these two limits that determine the final injection height.

Figure 5 shows a statistical analysis of all the data analysed in 2006 to highlight the relationships between the injection height, convective heat flux and the active fire area. We find an approximately linear relationship between the injection height and active fire area until we reach areas $>80$ ha. We also find a similar relationship between the injection height and heat flux (threshold $>50 \mathrm{~kW} \mathrm{~m}^{-2}$ ). Above a certain threshold of fire energy release rate and consumed active fire area, the buoyancy induced by the fire can overcome locally stable meteorological conditions, with resulting injection heights typically $>3.5 \mathrm{~km}$. Figure 5 also shows that the 


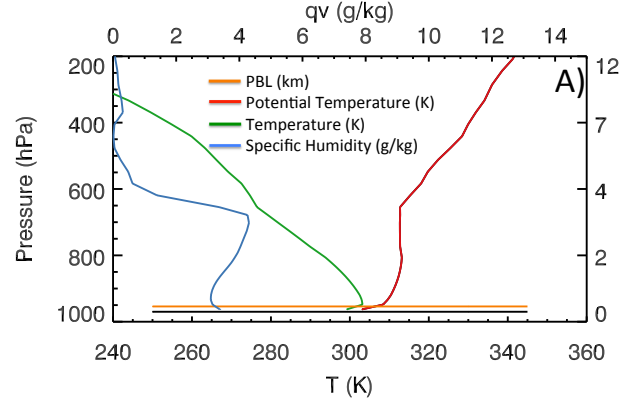

ZTOP: $0.1 \mathrm{~km}$ HF: $4.3 \mathrm{~kW} / \mathrm{m}^{2}$ A: $1.0 \mathrm{ha}$

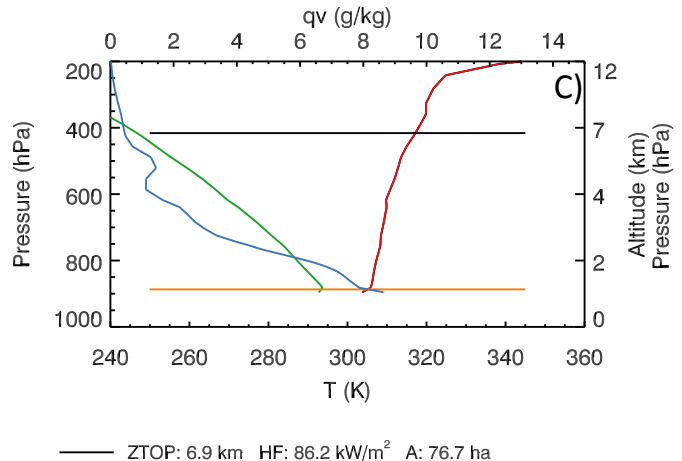

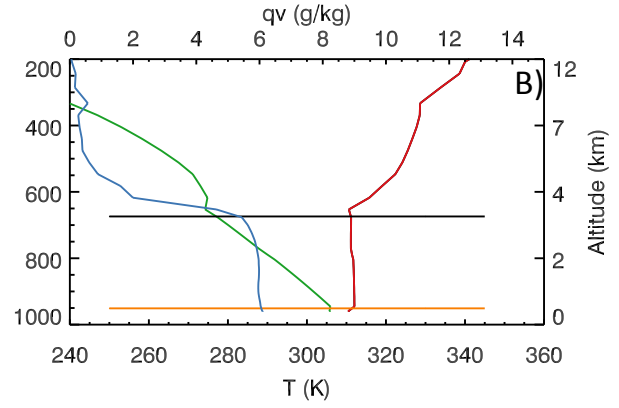

ZTOP: $3.3 \mathrm{~km}$ HF: $4.8 \mathrm{~kW} / \mathrm{m}^{2}$ A: 0.7 ha

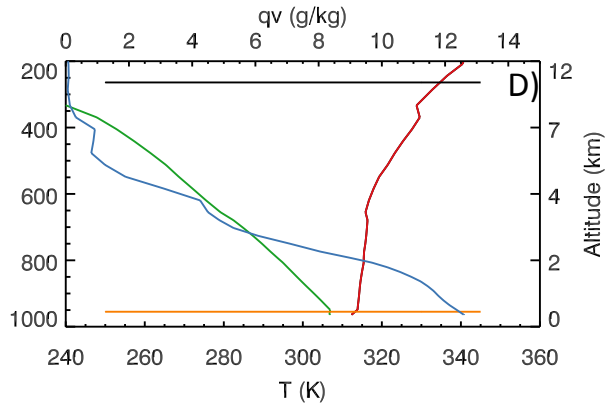

ZTOP: $10.0 \mathrm{~km} \quad \mathrm{HF}: 154.0 \mathrm{~kW} / \mathrm{m}^{2}$ A: $80.8 \mathrm{ha}$

Figure 4. Sensitivity of injection height to varying atmospheric profiles of temperature $(\mathrm{K})$ and specific humidity ( $\left.\mathrm{g} \mathrm{Kg}^{-1}\right)$. The solid horizontal lines denote the injection height ZTOP $(\mathrm{km})$ and local boundary layer heights (BL), respectively. Red, green, and blue vertical profiles denote potential temperature, temperature, and specific humidity $q_{v}\left(\mathrm{~g} \mathrm{~kg}^{-1}\right)$, respectively. Convective heat flux (HF, $\mathrm{kW} \mathrm{m}{ }^{-2}$ ), active fire size (A, ha) and corresponding injection height (ZTOP, km) are shown in panel-specific legends. Not all profiles start at $1000 \mathrm{hPa}$ due to the local terrain. Panels (a) and (b) include profiles over Africa $\left(+17.5^{\circ} /+10^{\circ}\right)$ and over the Amazon Basin $\left(-55^{\circ} /-14^{\circ}\right)$ with ZTOP values of $0.1 \mathrm{~km}$ and $3.3 \mathrm{~km}$, respectively. Panels (c) and (d) include profiles over Canada $\left(-122^{\circ} /+56^{\circ}\right)$ and over Australia $\left(+130^{\circ} /-20^{\circ}\right)$ with ZTOP values of $6.9 \mathrm{~km}$ and $10.0 \mathrm{~km}$, respectively.
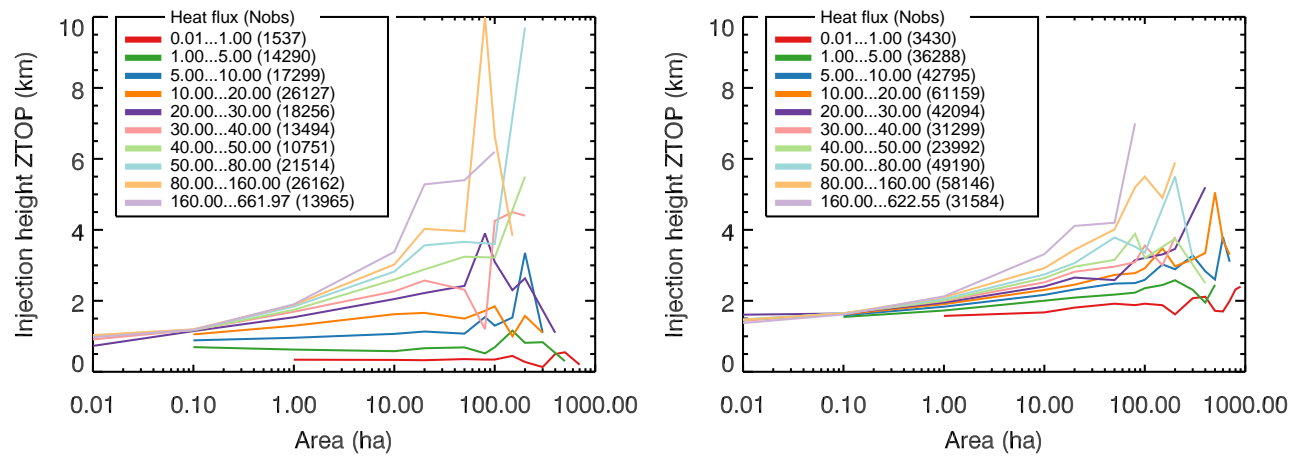

Figure 5. Injection heights as a function of MODIS-derived active fire area (ha) and convective heat flux $\left(\mathrm{kW} \mathrm{m}^{-2}\right)$ during 2006 . The number of observations (Nobs) per bin of heat flux is given in parentheses. The left panel shows instances where there is a stable atmosphere in the first few levels determined by a positive vertical gradient in potential temperature, and the right panel shows instances with an unstable atmosphere.

meteorological stability conditions play a progressively important role as the active fire area and heat flux increases.

Previous work derived a plume height climatology based on a compilation of derived MISR (Multi-angle Imaging SpectroRadiometer) stereo height retrievals using the MINX algorithm Nelson et al. (2013). These data were used to test the ability of a 1-D plume rise model, initialized with different combinations of derived heat-flux and active fire area, in predicting the injection heights inferred from the MISR spaceborne instrument Diner et al. (2010) during the 2002, 

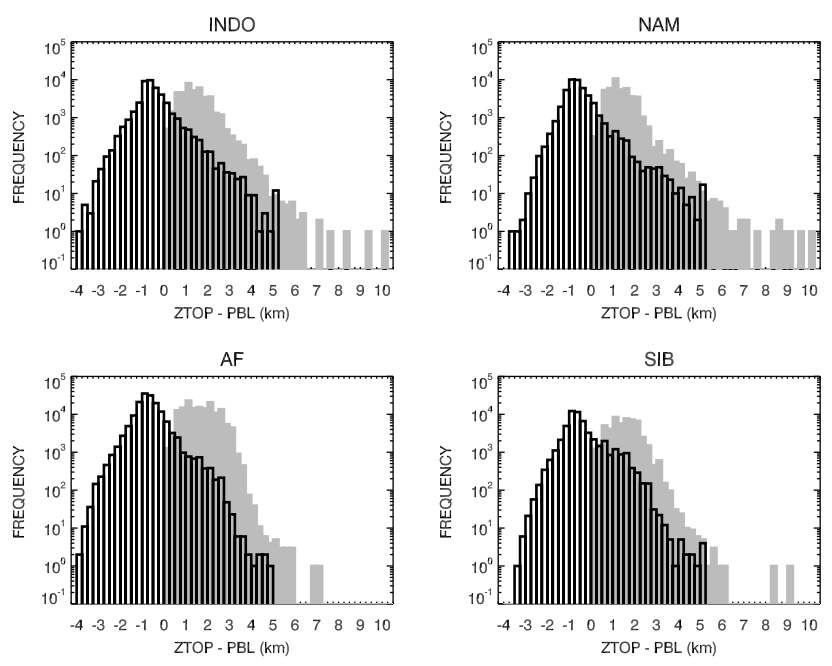

Figure 6. Distribution of injection height (ZTOP) minus the local boundary layer $(\mathrm{BL})+250 \mathrm{~m}$ for four example burning regions around the globe: INDO (Indonesia), NAM (North America), AF (Africa), and SIB (Siberia). The grey area represents the distribution of injection heights. The ordinate is in log-space.

2004 and 2007 North American burning seasons. They found that the plume rise model typically underpredicted the injection heights into the free troposphere due to the uncertain nature of input parameters as FRP, fire area, and environmental meteorological conditions. A previous study showed that the model often overpredicts low injections but always underpredicts for high fire injections Val Martin et al. (2012). The authors in that paper argue that a pre-compiled classification of injection heights as a function of parameters described in a lookup table may be an efficient approach to including injection heights in global models. While we agree that there is an urgent need for a predictive capability for plume rise, we believe that finding a robust relationship with injection height may well be as uncertain as using the plume rise model itself. We find that one of the biggest uncertainties is identifying the stability of the overlying atmosphere given the coarse meteorological information from global models. We emphasize that we agree with the findings of Val Martin et al. (2012) that the uncertainty of detrainment and entrainment processes in the plume rise model could be the largest source of overall model error.

Figure 6 shows that the normalized frequency distribution of injection heights over key burning regions is consistent, with differences only in the extent of the tails. This suggests that in almost all biomass burning regions smaller and less intense fires dominate with differences due mainly to the number of extreme fires, and how extreme they are. For brevity we focus on a few regions. The median injection height for all regions is $\simeq 1.5 \mathrm{~km}$, with the highest injection heights of $>6 \mathrm{~km}$ over Indonesia, Africa, North America and Siberia. Once we subtract the local BL $+250 \mathrm{~m}$ layer (taking into account uncertainty of the BL value) from this we find that typ- ically $20 \%$ of fires are injected above the BL, consistent with bulk statistics reported in previous work Val Martin et al. (2010). If we increase the free troposphere threshold to the local $\mathrm{BL}+500 \mathrm{~m}$, we find that the fraction of fire reaching the free troposphere drops to $10-20 \%$, where Africa, Asia and North America are most affected, suggesting these fires only just reach the free troposphere.

Val Martin et al. (2012) studied 584 MISR plumes over North America for the years 2002, 2006-2007 and their scaled-FRP/FRPx10 set-up found that 16-35\% (500-250 m BL uncertainty) reached the free troposphere compared to $24-48 \%$ observed by MISR. We find that over North America during 2006, 14-22\% (500-250 m BL uncertainty) reaches the free troposphere. While the percentage of model plumes reaching the free troposphere over North America is similar to MISR observations, it is not necessarily the same group of plumes Val Martin et al. (2010).

We use land cover classifications from AVHRR and MODIS observations Hansen et al. (2000); Friedl et al. (2002) to investigate the relationship between the land cover (savannah, agriculture, peat, tropical and extratropical forest), FRP of fires and the resulting injection heights. We find that agricultural fires have a median FRP of $20 \mathrm{MW}$ and are typically lower than over the other four biomes that have median values of $30 \mathrm{MW}$ (not shown). The corresponding injection height means are similar for all vegetation types with the exception of agricultural vegetation for which the mean height is $<5 \mathrm{~km}$. Agricultural fires are small and typically of low intensity, resulting in what would be expected to be low FRP for the fires when compared, for example, to many other types of fire. We also found no evidence to support that injection heights for extratropical forests were higher than from other biomes.

\subsection{The sensitivity of atmospheric $\mathrm{CO}$ to pyroconvection}

We use the GEOS-Chem atmospheric chemistry transport model (Sect. 3.2) to vertically distribute biomass burning emissions of $\mathrm{CO}$ according to the scene-dependent MODIS FRP-inferred injection height to understand the impact on atmospheric CO distributions. We then compare this model output to see whether it improves agreement with available data relative to the model that assumes an injection height that is limited to the BL.

To help evaluate our model during 2006, we use exclusively spaceborne observations of CO from the v5 MOPITT CO profile retrievals Deeter et al. (2013). The two major airborne campaigns, MOZAIC Marenco et al. (1998) and INTEX-B Arellano Jr. et al. (2007), that measured CO during this period are not ideal for studying biomass burning. Previous work has shown that MOPITT data can be used to estimate emissions of $\mathrm{CO}$ from biomass burning (e.g. Pfister et al., 2005; Arellano Jr. et al., 2006; Chevallier et al., 2008; Kopacz et al., 2009; Gonzi et al., 2011a, b) but there still exist 

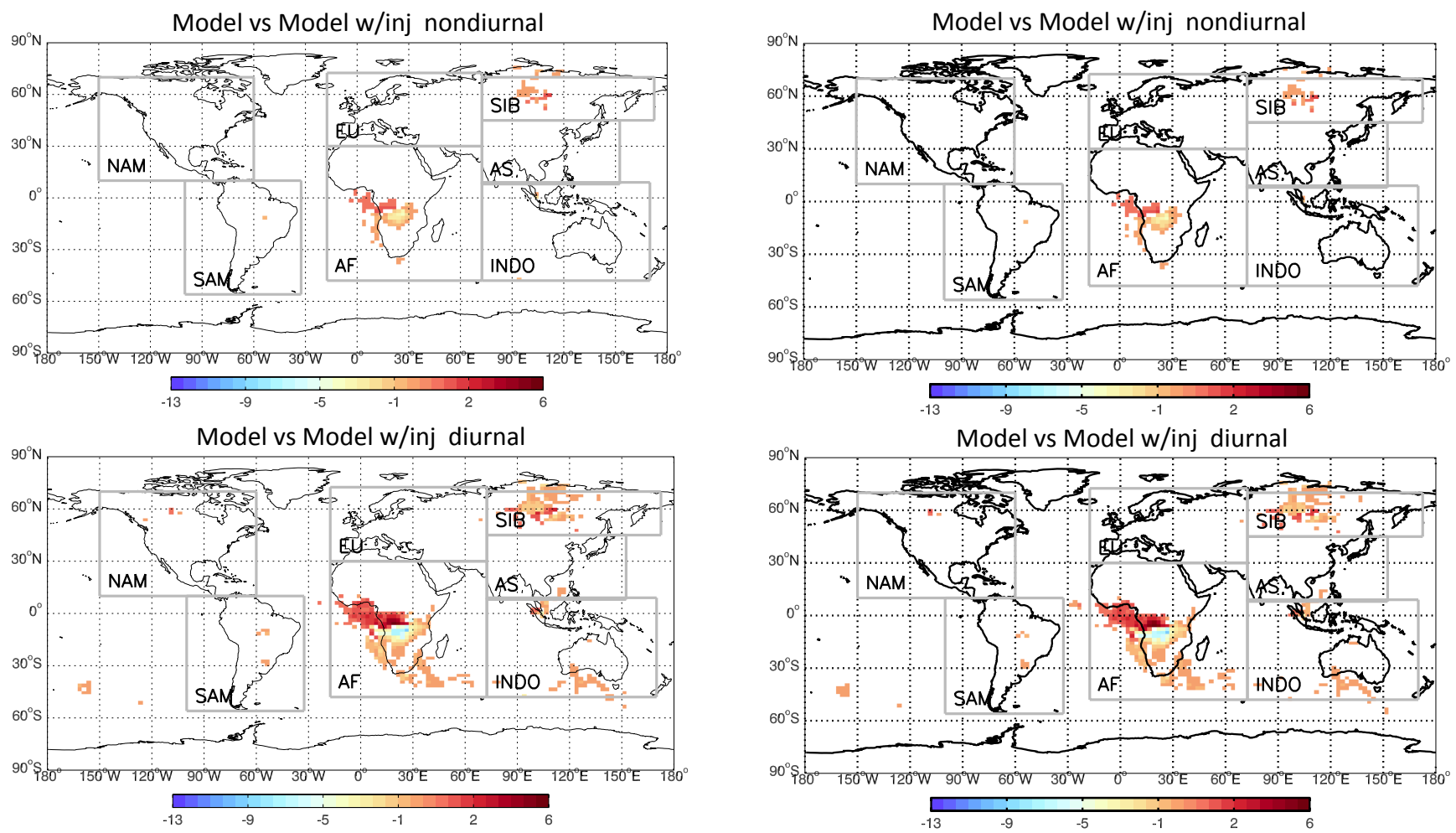

Figure 7. Top panel: CO total column bias (\%) between model and model with injection height in GEOS-Chem model space for the month of July 2006. Title indicates nondiurnal or diurnal FRP cycle. Note: we sample the model at the time and location of each MOPITT observation.

large uncertainties associated with the magnitude and timing of these emissions, reflecting model errors and also the coverage and uncertainties associated with MOPITT. As discussed in Sect. 3.2, we sample the model at the time and location of each MOPITT scene and convolve the resulting profile in log-space with scene-specific averaging kernels (see Eq. 2).

Figure 7 shows that the model using the injection height estimate inferred from MODIS as a monthly mean value has the largest differences $(-5$ to $+2 \%)$, relative to the control, over and downwind of central and southern Africa. Including our diurnal variation of FRP (Fig. 2) increases the magnitude and spatial extent of the differences over and downwind of Africa and also introduces differences over Siberia and to a lesser extent over Southeast Asia and Australia. As Fig. 8 shows, even when we use a different selection criterion for thinning the MOPITT data, there are only minor localized differences and the results do not change. A cross-section plot along the latitudes vs. altitude (Fig. 9) shows that the largest averaged monthly negative bias occurs in the BL at $\approx-12^{\circ}$ latitude, corresponding to the largest negative bias in the total columns. If we then convolve the model profiles with scene-dependent MOPITT averaging kernels, these differences (not shown) are substantially reduced to $< \pm 2 \%$. We find that the differences $( \pm 50 \%)$ between model values,

Figure 8. Same as Fig. 7 but with a more relaxed DOF criterion for thinning the MOPITT data (see Sect. 2.3). Top panel: CO total column bias (\%) between model and model with injection height in GEOS-Chem model space for the month of July 2006. Title indicates nondiurnal or diurnal FRP cycle.

as would be observed by MOPITT space with MOPITT data, are an order of magnitude larger (see Figs. 10 and 11) than those introduced by using different formulations of injection height.

In general, we find that the model bias against MOPITT, largely due to errors in prior emission inventories, is an order of magnitude larger than the model response convolved with MOPITT averaging kernels to different prescriptions of injection height.

Previous work used the GEOS-Chem model to infer CO emissions from MOPITT v5 CO profiles between June and August 2006 Jiang et al. (2012). This work found that posterior emission estimates were sensitive to the pressure levels used: GEOS-Chem over(under)-estimates CO at lower (middle and upper) levels. The authors did not account for injection height, however, and as Fig. 9 shows accounting for injection height will not necessarily reduce $\mathrm{CO}$ concentrations within the boundary layer. Figure 9 shows, for the diurnal FRP cycle, that accounting for injection height will increase the $\mathrm{CO}$ concentrations (bias $<0 \%$ ) in the BL between the latitude cross section -10 and $-20^{\circ}$, but will decrease $\mathrm{CO}$ concentrations between 0 and $-10^{\circ}$. The decrease of $\mathrm{CO}$ concentrations is a consequence of the injection height and 

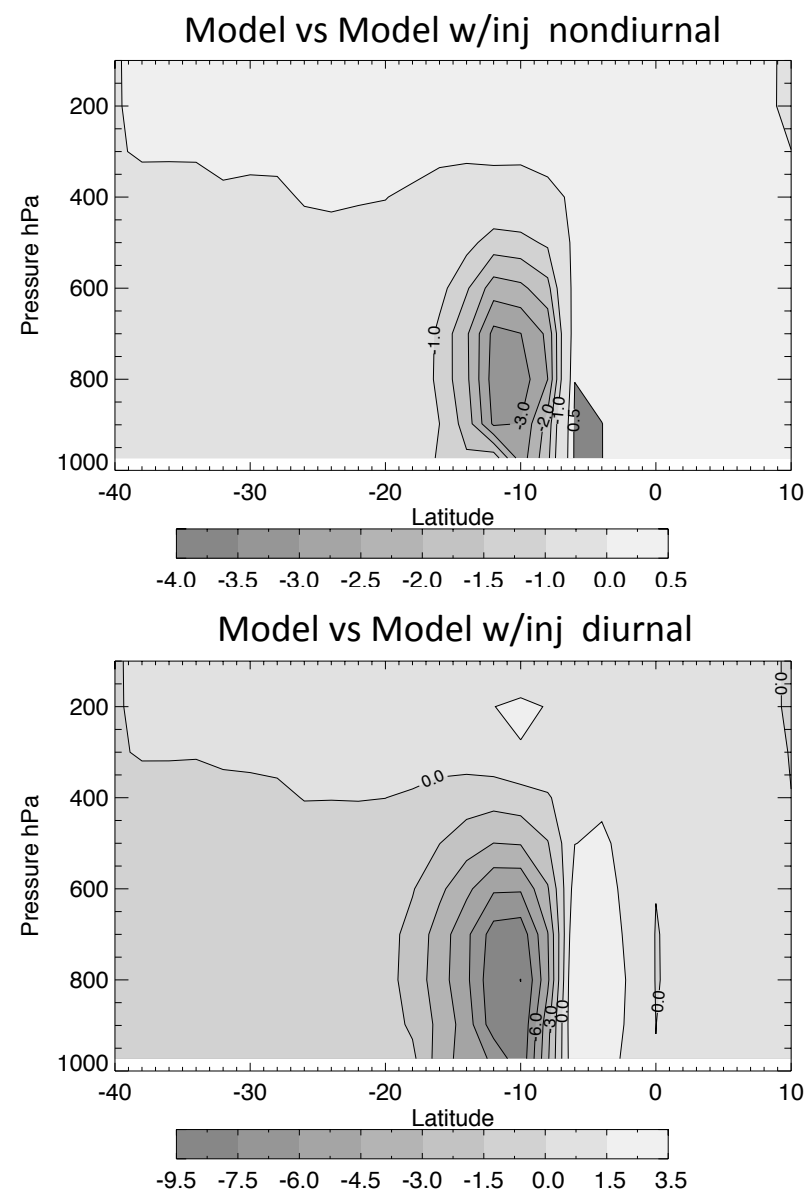

Figure 9. CO concentration bias (\%) along latitude versus altitude at $\approx 17^{\circ}$ longitude for July 2006 . The title indicates use of nondiurnal (top) or diurnal (bottom) FRP cycles. A negative bias means the model without injection height (control run) is lower than the model with MODIS-derived injection heights, and vice versa.

model transport and corresponds to the location of maximum injection heights in Africa (see Fig. 1f, g). Emissions injected into the free troposphere are quickly advected, hence the positive bias (control run $>$ model with injection height).

Figure 12 shows an example of model and MOPITT CO profiles over Siberian forest fires. The difference of model $\mathrm{CO}$ mixing ratio with and without MODIS-inferred injection height using our diurnal distribution is $30-80 \mathrm{ppb}$ in the lower troposphere. After we relate model $\mathrm{CO}$ concentrations to $\mathrm{CO}$ concentrations which are observed by $\mathrm{MO}-$ PITT using the relevant averaging kernel (Fig. 12) the difference between the two models reduces to $<10 \mathrm{ppb}$. We find the resulting model profile overestimates (underestimates) $\mathrm{CO}$ at the surface (in the free troposphere), relative to MOPITT. The corresponding column amounts are $3.3 \times$ $10^{18}$ molec cm $^{-2}$ for MOPITT and $2.4 \times 10^{18}$ molec cm $^{-2}$

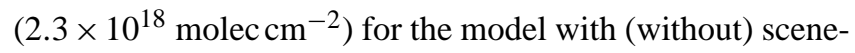
dependent injection height. For this example, it is clear that the model minus MOPITT bias of $27 \%$ is much larger than

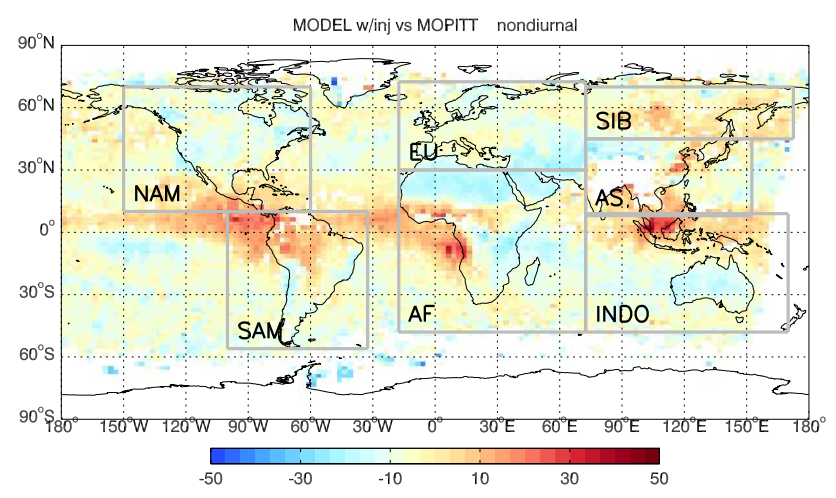

Figure 10. CO total column bias (\%) between model with injection height and MOPITT for the month of July 2006. White areas indicate a bias of $\approx 0 \%$.

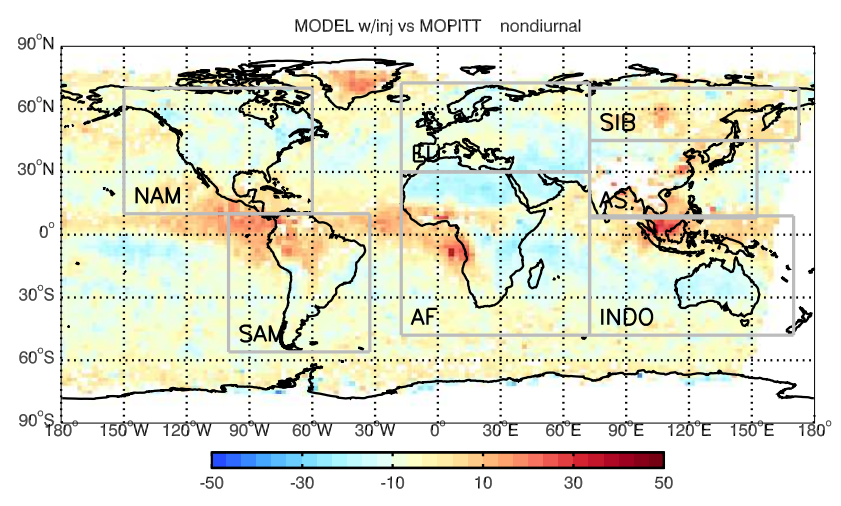

Figure 11. Same as Fig. 10 but with a more relaxed DOF criterion for thinning the MOPITT data (see Sect. 2.3). CO total column bias $(\%)$ between model with injection height and MOPITT for the month of July 2006. White areas indicate a bias of $\approx 0 \%$.

the $5 \%$ difference between the two model calculations. We find similar instances over the other burning loci around the world. We show this example profile because it corresponds to the time and location of the largest bias $(\approx 5 \%)$ between model with/without injection height over the region of SIB (Fig. 7). MOPITT profiles have generally finer vertical resolution.

For the above calculations we have assumed that material is distributed uniformly from the surface or boundary layer to the prescribed injection height. We consider two alternative formulations. First, we take into account that the majority of surface fires will typically be $<2^{\circ} \times 2.5^{\circ}\left(\approx 62500 \mathrm{~km}^{2}\right)$, and acknowledge that only the most intense of these will play a substantial role in determining atmospheric composition. We select the fires within the top 20th percentile of global injection heights $(>2.2 \mathrm{~km})$ and artificially (and crudely) increase the associated emissions by a factor of 4 . We denote this simulation InJS1. Second, we take into account that the injection height is only a crude measure of the atmospheric flow, and that detrainment of the vertical flow gen- 

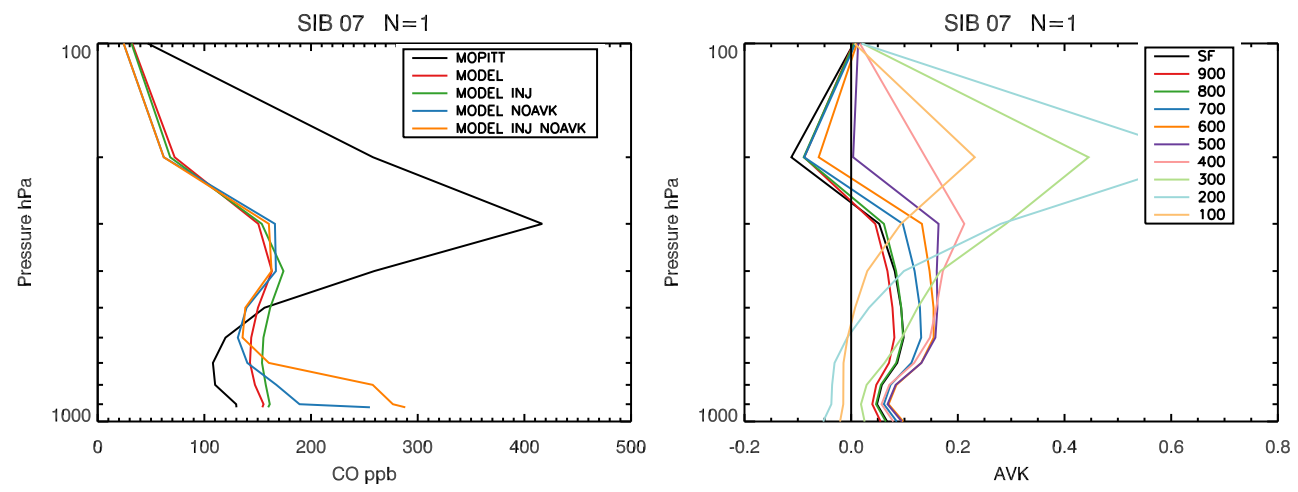

Figure 12. Observed CO profile (ppb) from MOPITT in July 2006 over Siberia and comparison to model profiles with (MODEL INJ) and without (MODEL) injection height. NOAVK denotes the profiles in GEOS-Chem model space. The title denotes the region and month. The model profiles shown here are for the diurnal FRP cycle. The right plot shows the corresponding MOPITT averaging kernels (AVK) from the surface (SF) to $100 \mathrm{hPa}$.

erated by eddies in the mixing processes will deposit emissions at heights below the highest value. To address this we incorporate a normalized parabolic injection height profile with a half-width maximum of $1 \mathrm{~km}$ such that the profile integrates to unity (InJS2). For both sensitivity runs we produce a corresponding control run that can be used to assess the importance of the parameter being perturbed. We find that the maximum total column bias in Fig. 7 is about a factor of 2 larger for InJS1 than for InJS2 (not shown), although the spatial distribution of the bias is the same, as expected, but is still small compared to the model minus MOPITT differences. We argue that MOPITT averaging kernels are too broad to distinguish between different prescribed vertical injection heights due to fire-induced convection. This is reflected in more detailed analyses involving MAP algorithms for which we find only small adjustments to posterior emissions compared to differences due to emissions that have been published previously (e.g. Gonzi et al., 2011a). We therefore do not discuss this any further.

\section{Concluding remarks}

We presented the first global, annual study of spaceborne observations of fire radiative power and fire area to study the resulting injection heights. We used MODIS FRP and active fire area observations for 2006 to improve the understanding of their relationship and the resulting injection height by embedding a 1-D plume rise model into a global 3-D chemistry transport model.

Based on our data and models, we did not find a strong relationship between FRP, active fire area and injection height. This is in contrast to other studies Sofiev et al. (2012). We suggest, based on our analysis, a robust relationship may be as uncertain as using these data to determine scene-specific initial conditions for a 1-D plume rise model.
We demonstrated, using a plume rise model, that different prescriptions of injection height do have an impact on the distribution and concentration of model $\mathrm{CO}$ over intense fires. However, transformation of model $\mathrm{CO}$ concentration into MOPITT measurement space using scene-dependent averaging kernels greatly reduces this impact. This is largely due to the vertical broadness of averaging kernels. Therefore, it cannot a priori be assumed that MOPITT is sensitive to different prescriptions of biomass burning injection height. In general, model bias against MOPITT can be as large as $50 \%$, which dwarfs any realistic perturbation from the redistribution of $\mathrm{CO}$ mass within a vertical column after being convolved with scene-dependent MOPITT averaging kernels. We have shown examples over large fires where MOPITT measurements can differentiate between different prescriptions of the vertical transport of $\mathrm{CO}$ coming from fires. But those instances are relatively rare and, for most fires, MOPITT measurements of $\mathrm{CO}$ are largely insensitive to the injection height. As a consequence, injection height does not significantly affect $\mathrm{CO}$ emission estimates inferred from MOPITT data. The major implication from this result is that outside of detailed case studies, the use of MOPITT to quantify biomass burning emissions is biased towards the very largest fires that can perturb substantial sections of the observed atmospheric column. Spaceborne retrievals of FRP and active fire area, together with atmospheric concentration measurements of fire-emitted species such as $\mathrm{CO}$, will be more effective together than individually when used as constraints for biomass burning emissions and their associated vertical transport. More thorough use of these types of data may, however, require assimilation within a model that explicitly includes these observed parameters.

Interpreting NIR/TIR observations of $\mathrm{CO}$ from the $\mathrm{MO}$ PITT instrument currently offers us insights into the spatial and temporal distributions of biomass burning emissions. However, our study has shown there are limitations to these data in understanding pyrogenic emissions that lie far beyond 
the original science and instrument requirements. The nextgeneration instruments that will focus on addressing gaps in our understanding of biomass burning will observe simultaneously the spectral regions that are sensitive to changes in atmospheric trace gases and aerosols and land-surface properties. Previous analysis of the atmospheric signature from biomass burning using spaceborne data has focused on $\mathrm{CO}$ using thermal IR sensors such as MOPITT with greatest sensitivity in the free troposphere, or short-lived trace gases such as formaldehyde measured by $\mathrm{UV} / \mathrm{Vis}$ sensors that require a detailed knowledge of atmospheric chemistry (e.g. Gonzi et al., 2011b). An ideal mission concept would have a vertical resolution $<1 \mathrm{~km}$ in the lower and free troposphere and a ground-pixel size of $1 \mathrm{~km}$ or less, sufficient to capture expected variations in the land surface and in the atmosphere. To achieve this, a combined nadir/limb viewing instrument that measures thermal and short-wave IR wavelength may be required, but integrating these data brings its own challenges (e.g. Gonzi and Palmer, 2010). 


\section{Appendix A}

The plume rise model variables are solved on a vertical grid comprising 200 levels in steps of $100 \mathrm{~m}$. We extended the original model by introducing a mass conservation variable $\zeta$ Paugam et al. (2010).

$\frac{\partial w}{\partial t}+w \frac{\partial w}{\partial z}=\frac{1}{1+\gamma} g B-\epsilon w^{2}$,

$\frac{\partial T}{\partial t}+w \frac{\partial T}{\partial z}=-w \frac{g}{c_{p}}-\epsilon w(T-\bar{T})+\frac{\partial T}{\partial t}$ micro,

$\frac{\partial \zeta}{\partial t}=\frac{\partial w \zeta}{\partial z}+w \zeta(\epsilon-\delta)$,

$\frac{\partial \phi}{\partial t}+w \frac{\partial \phi}{\partial z}=-\epsilon w\left(\phi-\phi_{\mathrm{e}}\right)$,

$\zeta=\rho R^{2}$

$\epsilon=\max \left(0, C_{\epsilon} \frac{B}{w^{2}}\right)+C_{\epsilon} \frac{1}{w} \frac{\mathrm{d} u}{\mathrm{~d} z}$,

$\delta=\max \left(0, C_{\delta} \frac{B}{w^{2}}\right)+C_{\delta} C_{\epsilon} \frac{1}{w} \frac{\mathrm{d} u}{\mathrm{~d} z}$,

where $w$ denotes vertical plume velocity $\left(\mathrm{m} \mathrm{s}^{-1}\right), T(\mathrm{~K})$ is the plume temperature, $T_{\mathrm{e}}(\mathrm{K})$ is the environmental temperature, $B(\mathrm{~kg})$ is the buoyancy $(g B), g\left(\mathrm{~m} \mathrm{~s}^{-2}\right)$ gravitational constant, $\gamma$ (unitless) scaling factor, $c_{p}\left(\mathrm{~J} \mathrm{~kg}^{-1} \mathrm{~K}^{-1}\right)$ specific heat for constant pressure, $\zeta$ mass $\left(\mathrm{kg} \mathrm{m}^{-1}\right), \epsilon\left(1 \mathrm{~s}^{-1}\right)$ and $\delta\left(1 \mathrm{~s}^{-1}\right)$ denote entrainment and detrainment, respectively, $C_{\epsilon}$ (unitless) and $C_{\delta}$ (unitless) are empirical scaling factors (Pergaud et al., 2009), and $u\left(\mathrm{~m} \mathrm{~s}^{-2}\right)$ denotes the horizontal velocity of the centre of the plume at level $z$. The subscript micro takes into account evaporation, condensation, rain, and ice with respect to the saturation water mass mixing ratio.

The initial boundary conditions rely on GEOS-5 temperatures, relative humidity (available water), and wind fields. The active fire area and convective heat flux, respectively, are based on MODIS-derived observations (see main text). As mentioned in the main text, we calculate the available water $\left(\mathrm{g} \mathrm{m}^{-2}\right)$ from the fuel by a simple formula and add it to the environmentally available water in the first vertical model grid box:

water $=\frac{\mathrm{HF} \times \frac{\mathrm{d} t}{H} \times\left(0.5+f_{\text {moist }}\right)}{0.55} \times 1000$,

where $\mathrm{HF}$ is the convective heat flux $\left(\mathrm{W} \mathrm{m}^{-2}\right), H$ is the fuel and its heat storage capacity $\left(\mathrm{J} \mathrm{kg}^{-1}\right), \mathrm{d} t$ is the time step $(s)$, and $f_{\text {moist }}$ is the moisture content of the fuel (unitless). We assume $f_{\text {moist }}$ has a ratio of $10 \%$. The factor 0.5 in the equation assumes $0.5 \mathrm{~kg}$ is being emitted as water per $1 \mathrm{~kg}$ of fuel burnt. For $H$ we chose a value of $19 \mathrm{MJ} \mathrm{kg}^{-1}$, representing typical fuel vegetation characteristics. 
Acknowledgements. We thank Saulo Freitas (INPE/CPTEC) for useful discussions regarding the plume rise model code. This work was supported by the UK Natural Environment Research Council grant NE/E01819X/1. P. I. Palmer gratefully acknowledges his Royal Society Wolfson Research Merit Award.

Edited by: A. Pozzer

\section{References}

Anderson, W. R., Catchpole, E. A., and Butler, B. W.: Convective heat transfer in fire spread through fine fuel beds, Int. J. Wildland Fire, 9, 284-298, 2010.

Arellano Jr., A. F., Kasibhatla, P. S., Giglio, L., van der Werf, G. R., Randerson, J. T., and Collatz, G. J.: Time-dependent inversion estimates of global biomass-burning CO emissions using Measurement of Pollution in the Troposphere (MOPITT) measurements, J. Geophys. Res., 111, D09303, doi:10.1029/2005JD006613, 2006.

Arellano Jr., A. F., Raeder, K., Anderson, J. L., Hess, P. G., Emmons, L. K., Edwards, D. P., Pfister, G. G., Campos, T. L., and Sachse, G. W.: Evaluating model performance of an ensemblebased chemical data assimilation system during INTEX-B field mission, Atmos. Chem. Phys., 7, 5695-5710, doi:10.5194/acp-75695-2007, 2007.

Barbosa, P. M., Stroppiana, D., and Gregoire, J.-M.: An assessment of vegetation fire in Africa (1981-1991): burned areas, burned biomass, and atmospheric emissions, Global Biogeochem. Cy., 13, 933-950, 1999.

Boschetti, L., Roy, D. P., Justice, C. O., and Giglio, L.: An assessment of vegetation fire in Africa (1981-1991): burned areas, burned biomass, and atmospheric emissions, Int. J. Wildland Fire, 19, 705-709, 2010.

Bowman, D. M. J. S., Balch, J. K, Artaxo, P., Bond, W. J., Carlson, J. M., Cochrane, M. A., D’Antonio, C. M., DeFries, R. S., Doyle, J. C., Harrison, S. P., Johnston, F. H., Keeley, J. E., Krawchuk, M. A., Kull, C. A., Marstona, J. B., Moritz, M. A., Prentice, I. C., Roos, C. I., Scott, A. C., Swetnam, T. W., van der Werf, G. R., and Pyne, S. J.: Fire in the Earth System, Science, 324, 481-484, 2009.

Butler, B. W.: Characterization of convective heating in full scale wildland fires, in: International Conference on Forest Fire Research, edited by: Viegas, D. X., 15-18 November 2010, Coimbra, Portugal, 2010.

Cahoon Jr., D., Stocks, B., Levine III, J., W. C., and O’Neill, K.: Seasonal distribution of African savanna fires, Nature, 359, 812815, 1992.

Carmona-Moreno, C., Belward, A., Malingreau, J., Hartley, A., Garcia-Algere, M., Antonovskiy, M., Buchshtaber, V., and Pivovarov, V.: Characterizing interannual variations in global fire calendar using data from Earth observing satellites, Glob. Change Biol., 11, 1537-1555, 2005.

Chevallier, F., Fortems, A., Bousquet, P., Pison, I., Szopa, S., Devaux, M., and Hauglustaine, D. A.: African CO emissions between years 2000 and 2006 as estimated from MOPITT observations, Biogeosciences, 6, 103-111, doi:10.5194/bg-6-103-2009, 2009.
Csiszar, I. A., Morisette, J. T., and Giglio, L.: Validation of active fire detection from moderate-resolution satellite sensors: the MODIS example in northern Eurasia, IEEE T. Geosci. Remote Sens., 44, 1757-1764, 2006.

Cunningham, P. and Reeder, M. J.: Severe convective storms initiated by intense wildfires: numerical simulations of pyroconvection and pyro-tornadogenesis, Geophys. Res. Lett., 36, L12812, doi:10.1029/2009GL039262, 2009.

Deeter, M. N.: MOPITT Measurements of Pollution in the Troposphere, Version 5 Product User's Guide, Tech. rep., available at: https://www2.acd.ucar.edu/sites/default/files/mopitt/v5_ users_guide_beta.pdf, 2011.

Deeter, M. N., Worden, H. M., Edwards, D. P., Gille, J. C., and Andrews, A. E.: Evaluation of MOPITT retrievals of lowertropospheric carbon monoxide over the United States, J. Geophys. Res., 117, D13306, doi:10.1029/2012JD017553, 2012.

Deeter, M. N., Martinez-Alonso, S., Edwards, D. P., Emmons, L. K., Gille, J. C., Worden, H. M., Pittman, J. V., Daube, B. C., and Wofsy, S. C.: Validation of MOPITT version 5 thermalinfrared, near-infrared, and multispectral carbon monoxide profile retrievals for 2000-2011, J. Geophys. Res., 118, 6710-6725, doi:10.1002/jgrd.50272, 2013.

Diner, D., Ackerman, T., Braverman, A., Bruegge, C., Chopping, M., Clothiaux, E., Davies, R., Girolamo, L. D., Kahn, R., Knyazikhin, Y., Liu, Y., Marchand, R., Martonchik, J., Muller, J., Nolin, A., Pinty, B., Verstraete, M., Wu, D., Garay, M., Kalashnikova, O., Davis, A., Davis, E., and Chipman, R.: Ten years of MISR observations from Terra: looking back, ahead, and in between, Proc. IEEE Int. Geosci. Remote Sens. Symp., 1297-1299, 2010.

Dirksen, R. J., Boersma, K. F., de Laat, P., Stammes, J., van der Werf, G., Martin, M. V., and Kelder, H. M.: An aerosol boomerang: rapid around-the-world transport of smoke from the December 2006 Australian forest fires observed from space, J. Geophys. Res., 114, D21201, doi:10.1029/2009JD012360, 2009.

Dozier, J.: A method for satellite identification of surface temperature fields of subpixel resolution, Remote Sens. Environ., 11, 221-229, 1981.

Duncan, B. N., Martin, R. V., Staudt, A. C., Yevich, R., and Logan, J. A.: Interannual and seasonal variability of biomass burning emissions constrained by satellite observations, J. Geophys. Res., 108, 4040, doi:10.1029/2002JD002378, 2003.

Duncan, B. N., Logan, J. A., Bey, I., Megretskaia, I. A., Yantosca, R. M., Novelli, P. C., Jones, N. B., and Rinsland, C. P.: Global budget of CO, 1988-1997: source estimates and validation with a global model, J. Geophys. Res., 111, D22301, doi:10.1029/2007JD008459, 2007.

Edwards, D. P., Emmons, L. K., Gille, J. C., Chu, A., Attié, J.-L., Giglio, L., Wood, S. W., Haywood, J., Deeter, M. N., Massie, S. T., Ziskin, D. C., and Drummond, J. R.: Satellite-observed pollution from Southern Hemisphere biomass burning, J. Geophys. Res., 111, D14312, doi:10.1029/2005JD006655, 2006.

Ferguson, S., Sandberg, D., and Ottmar, R.: Modelling the effect of land use changes on global biomass emissions, in: Biomass Burning and Its Inter-relationship With the Climate System, Springer, New York, 33-50, 2000.

Finney, M. A., Cohen, J. D., McAllister, S. S., and Jolly, W. M.: On the need for a theory of wildland fire spread, Int. J. Wildland Fire, 22, 25-36, doi:10.1071/WF11117, 2012. 
Fisher, J. A., Jacob, D. J., Purdy, M. T., Kopacz, M., Le Sager, P., Carouge, C., Holmes, C. D., Yantosca, R. M., Batchelor, R. L., Strong, K., Diskin, G. S., Fuelberg, H. E., Holloway, J. S., Hyer, E. J., McMillan, W. W., Warner, J., Streets, D. G., Zhang, Q., Wang, Y., and Wu, S.: Source attribution and interannual variability of Arctic pollution in spring constrained by aircraft (ARCTAS, ARCPAC) and satellite (AIRS) observations of carbon monoxide, Atmos. Chem. Phys., 10, 977-996, doi:10.5194/acp-10-977-2010, 2010.

Fleming, Z. L., Monks, P. S., and Manning, A. J.: Review: untangling the influence of air-mass history in interpreting observed atmospheric composition, Atmos. Res., 104-105, 1-39, doi:10.1016/j.atmosres.2011.09.009, 2012.

Frankman, D., Webb, B. W., Butler, B. W., Jimenez, D., Forthofer, J. M., Sopko, P., Shannon, K. S., Hiers, J. K., and Ottmar, R. D.: Measurements of convective and radiative heating in wildland fires, Int. J. Wildland Fire, 22, 157-165, doi:10.1071/WF11097, 2012.

Freeborn, P. H., Wooster, M. J., Hao, W. M., Ryan, C. A., Nordgren, B. L., Baker, S. P., and Ichoku, C.: Relationships between energy release, fuel mass loss, and trace gas and aerosol emissions during laboratory biomass fires, J. Geophys. Res., 113, D01301, doi:10.1029/2007JD008679, 2008.

Freitas, S., Longo, K. M., Dias, M. A. F. S., Dias, P. L. S., Chatfield, R., Prins, E., Artaxo, P., Grell, G. A., and Recuero, F. S.: Monitoring the transport of biomass burning emissions in South America, Environ. Fluid. Mech., 5, 135-167, 2005.

Freitas, S. R., Longo, K. M., and Andreae, M. O.: Impact of including the plume rise of vegetation fires in numerical simulations of associated atmospheric pollutants, Geophys. Res. Lett., 33, L17808, doi:10.1029/2006GL026608, 2006.

Freitas, S. R., Longo, K. M., Trentmann, J., and Latham, D.: Technical Note: Sensitivity of 1-D smoke plume rise models to the inclusion of environmental wind drag, Atmos. Chem. Phys., 10, 585-594, doi:10.5194/acp-10-585-2010, 2010.

Friedl, M., McIver, D., Hodges, J., Zhang, X., Muchoney, D., Strahler, A., Woodcock, C., Gopal, S., Schneider, A., Cooper, A., Baccini, A., Gao, F., and Schaaf, C.: Global land cover mapping from MODIS: algorithms and early results, Remote Sens. Environ., 83, 287-302, 2002.

Fromm, M., Lindsey, D. T., Yue, R. S. G., Sica, T. T. R., Doucet, P., and Godin-Beekmann, S.: The Untold Story of Pyrocumulonimbus, B. Am. Meteorol. Soc., 91, 1193-1209, doi:10.1175/2010BAMS3004.1, 2010.

Giglio, L., Descloitres, J., Justice, C. O., and Kaufman, Y. J.: An Enhanced Contextual Fire Detection Algorithm for MODIS, Remote Sens. Environ., 87, 273-282, 2003.

Giglio, L.: Characterization of the tropical diurnal cycle using VIRS and MODIS observations, Remote Sens. Environ., 108, 407-421, 2007.

Giglio, L. and Schroeder, W.: A global feasibility assessment of the bi-spectral fire temperature and area retrieval using MODIS data, Remote Sens. Environ., 108, 407-421, 2014.

Gonzi, S. and Palmer, P. I.: Vertical transport of surface fire emissions observed from space, J. Geophys. Res., 115, D02306, doi:10.1029/2009JD012053, 2010.

Gonzi, S., Feng, L., and Palmer, P. I.: Seasonal Cycle of Emissions of $\mathrm{CO}$ inferred from MOPITT profiles of CO: sensitivity to py- roconvection and profile retrieval assumptions, Geophys. Res. Lett., 38, L08813, doi:10.1029/2011GL046789, 2011 a.

Gonzi, S., Palmer, P. I., Barkley, M. P., Smedt, I. D., and Roosendael, M. V.: Biomass burning emission estimates inferred from satellite column measurements of HCHO: sensitivity to coemitted aerosol and injection height, Geophys. Res. Lett., 38 , L14807, doi:10.1029/2011GL047890, 2011b.

Govaerts, Y., Lattanzio, M. W. P. F. A., and Roberts, G.: Algorithm theoretical basis document for MSG SEVIRI Fire Radiative Power (FRP) characterization, Technical Report Series on Global Modeling and Data Assimilation, EUMETSAT (LSA SAF), 2010.

Hansen, M., DeFries, R., Townshend, J., and Sohlberg, R.: Global land cover classification at $1 \mathrm{~km}$ resolution using a decision tree classifier, Int. J. Remote Sens., 21, 1331-1365, 2000.

Hodzic, A., Madronich, S., Bohn, B., Massie, S., Menut, L., and Wiedinmyer, C.: Wildfire particulate matter in Europe during summer 2003: meso-scale modeling of smoke emissions, transport and radiative effects, Atmos. Chem. Phys., 7, 4043-4064, doi:10.5194/acp-7-4043-2007, 2007.

Horowitz, L. W., Walters, S., Mauzerall, D. L., Emmons, L. K., Rasch, P. J., Granier, C., Tie, X., Lamarque, J.-F., Schultz, M. G., Tyndall, G. S., Orlando, J. J., and Brasseur, G. P.: A global simulation of tropospheric ozone and related tracers: Description and evaluation of MOZART, J. Geophys. Res., 108, 4784 doi:10.1029/2002JD002853, 2003.

Ichoku, C. and Kaufman, Y.: A method to derive smoke emission rates from MODIS fire radiative energy measurements, IEEE T. Geosci. Remote. Sens., 43, 2636-2649, 2005.

Ichoku, C., Giglio, L., Wooster, M. J., and Remer, L. A.: Global characterization of biomass-burning patterns using satellite measurements of fire radiative energy, Remote Sens. Environ., 112, 2950-2962, doi:10.1016/j.atmosres.2012.03.007, 2008.

Ichoku, C., Kahn, R., and Chin, M.: Characterisation of GOME2 formaldehyde retrieval sensitivity, Atmos. Res., 111, 1-28, doi:10.1016/j.atmosres.2012.03.007, 2012.

Ito, A. and Penner, J. E.: Global estimates of biomass burning emissions based on satellite imagery for the year 2000, J. Geophys. Res., 109, D14S05, doi:10.1029/2003JD004423, 2004.

Jiang, Z., Jones, D. B. A., Worden, H. M., Deeter, M. N., Henze, D. K., Worden, J., Bowman, K. W., Brenninkmeijer, C. A. M., and Schuck, T.: Impact of model errors in convective transport on CO source estimates inferred from MOPITT CO retrievals, J. Geophys. Res., 118, 2073-2083, doi:10.1002/jgrd.50216, 2012.

Jordan, N., Ichoku, C., and Hoff, R.: Estimating smoke emissions over the U.S. southern Great Plains using MODIS fire radiative power and aerosol observations, Atmos. Environ., 42, 2007 2022, 2008.

Kaiser, J. W., Heil, A., Andreae, M. O., Benedetti, A., Chubarova, N., Jones, L., Morcrette, J.-J., Razinger, M., Schultz, M. G., Suttie, M., and van der Werf, G. R.: Biomass burning emissions estimated with a global fire assimilation system based on observed fire radiative power, Biogeosciences, 9 , 527-554, doi:10.5194/bg-9-527-2012, 2012.

Kalnay, E., Kanamitsu, M., Kistler, R., Collins, W., Deaven, D., Gandin, L., Iredell, M., Saha, S., White, G., Woollen, J., Zhu, Y., Leetmaa, A., Reynolds, B., Chelliah, M., Ebisuzaki, W., Higgins, W., Janowiak, J., Mo, K. C., Ropelewski, C., Wang, J., Jenne, R., 
and Joseph, D.: The NCEP/NCAR 40-years Reanalysis Project, B. Am. Meteorol. Soc., 77, 437-471, 1996.

Kasischke, E. and Penner, J. E.: Improving global estimates of atmospheric emissions from biomass burning, J. Geophys. Res., 109, D14S01, doi:10.1029/2004JD004972, 2004.

Kopacz, M., Jacob, D., Henze, D., Heald, C., Streets, D., and Zhang, Q.: Comparison of analytical and adjoint Bayesian inversion methods for constraining Asian sources of CO using satellite (MOPITT) measurements of CO columns, J. Geophys. Res., 114, 1-10, 2009.

Lavoué, D. C., Liousse, C., Cachier, H., Stocks, B., and Goldhammer, J.: Modelling of carbonaceous particles emitted by boreal and temperature wildfires at northern latitudes, J. Geophys. Res., 105, 26871-26890, 2000.

Liousse, C., Guillaume, B., Grégoire, J. M., Mallet, M., Galy, C., Pont, V., Akpo, A., Bedou, M., Castéra, P., Dungall, L., Gardrat, E., Granier, C., Konaré, A., Malavelle, F., Mariscal, A., Mieville, A., Rosset, R., Serça, D., Solmon, F., Tummon, F., Assamoi, E., Yoboué, V., and Van Velthoven, P.: Updated African biomass burning emission inventories in the framework of the AMMA-IDAF program, with an evaluation of combustion aerosols, Atmos. Chem. Phys., 10, 9631-9646, doi:10.5194/acp10-9631-2010, 2010.

Marenco, A., Thouret, V., Nedelec, P., Smit, H., Helten, M., Kley, D., Karcher, F., Simon, P., Law, K., Pyle, J., Poschmann, G., Wrede, R. V., Hume, C., and Cook, T.: Measurements of ozone and water vapour by Airbus in-service aircraft: the MOZAIC airborne program, J. Geophys. Res., 103, 25631-25642, 1998.

Martin, R., Jacob, D., Chance, K., Kurosu, T., Palmer, P., and Evans, M.: Global inventory of nitrogen oxide emissions constrained by space-based observations of $\mathrm{NO}_{2}$ columns, J. Geophys. Res., 108, 4537, doi:10.1029/2003JD003453, 2003.

Mu, M., Randerson, J. T., van der Werf, G. R., Giglio, L., Kasibhatla, P., Morton, D., Collatz, G. J., DeFries, R. S., Hyer, E. J., Prins, E. M., Griffith, D. W. T., Wunch, D., Toon, G. C., Sherlock, V., and Wennberg, P.: Daily and 3-hourly variability in global fire emissions and consequences for atmospheric model predictions of carbon monodixde, J. Geophys. Res., 116, D24303, doi:10.1029/2011JD016245, 2011.

Nelson, D. L., Garay, M. J., Kahn, R. A., and Dunts, B. A.: Stereoscopic Height and Wind Retrievals for Aerosol Plumes with the MISR INteractive eXplorer (MINX), Remote Sens. Environ., 5, 4593-4628, doi:10.3390/rs5094593, 2013.

Olivier, J. and Berdowski, J.: Global emissions sources and sinks, in: The Climate System, edited by: Berdowski, J., Guicherit, R., and Heij, B. J., 33-78, A.A. Balkema Publishers/Swets \& Zeitlinger Publishers, Lisse, The Netherlands, ISBN 905809 255, 2001.

Palmer, P. I., Parrington, M., Lee, J. D., Lewis, A. C., Rickard, A. R., Bernath, P. F., Duck, T. J., Waugh, D. L., Tarasick, D. W., Andrews, S., Aruffo, E., Bailey, L. J., Barrett, E., Bauguitte, S. J.B., Curry, K. R., Di Carlo, P., Chisholm, L., Dan, L., Forster, G., Franklin, J. E., Gibson, M. D., Griffin, D., Helmig, D., Hopkins, J. R., Hopper, J. T., Jenkin, M. E., Kindred, D., Kliever, J., Le Breton, M., Matthiesen, S., Maurice, M., Moller, S., Moore, D. P., Oram, D. E., O'Shea, S. J., Owen, R. C., Pagniello, C. M. L. S., Pawson, S., Percival, C. J., Pierce, J. R., Punjabi, S., Purvis, R. M., Remedios, J. J., Rotermund, K. M., Sakamoto, K. M., da Silva, A. M., Strawbridge, K. B., Strong, K.,
Taylor, J., Trigwell, R., Tereszchuk, K. A., Walker, K. A., Weaver, D., Whaley, C., and Young, J. C.: Quantifying the impact of BOReal forest fires on Tropospheric oxidants over the Atlantic using Aircraft and Satellites (BORTAS) experiment: design, execution and science overview, Atmos. Chem. Phys., 13, 6239-6261, doi:10.5194/acp-13-6239-2013, 2013.

Paugam, R., Wooster, M., Papadakis, G., and Schultz, M.: Estimation of the injection height of biomass burning emission, in: Proceeding in the ESA-iLEAPS-EGU joint conference, Frascati, Italy, 3-5 November 2010, European Space Agency, 2010.

Penner, J. E., Haselman, L. C., and Edwards, L. L.: Smoke-plume distributions above large-scale fires: implications for simulations of nuclear winter, Appl. Met., 25, 1434-1444, 1986.

Pergaud, J., Masson, V., Malardel, S., and Couvreux, F.: A parameterization of dry thermals and shallow cumuli for mesoscale numerical weather prediction, Bound.-Lay. Meteorol., 132, 132106, 2009.

Peterson, D., Wang, J., Ichoku, C., Hyer, E., and Ambrosia, V.: A sub-pixel-based calculation of fire radiative power from MODIS observations: Algorithm development and initial assessment, Remote Sens. Environ., 129, 262-279, 2013.

Pfister, G., Hess, P. G., Emmons, L. K., Lamarque, J.-F., Wiedinmyer, C., Edwards, D. P., Pétron, G., Gille, J. C., and Sachse, G. W.: Quantifying CO emissions from the 2004 Alaskan wildfires using MOPITT CO data, Geophys. Res. Lett., 32, L11809, doi:10.1029/2005GL022995, 2005.

Pfister, G. G., Avise, J., Wiedinmyer, C., Edwards, D. P., Emmons, L. K., Diskin, G. D., Podolske, J., and Wisthaler, A.: CO source contribution analysis for California during ARCTASCARB, Atmos. Chem. Phys., 11, 7515-7532, doi:10.5194/acp11-7515-2011, 2011.

Potter, B. E.: The role of released moisture in the atmospheric dynamics associated with wildland fires, Int. J. Wildland Fire, 14, 77-84, 2005.

Rienecker, M. M., Suarez, M., Todling, R., Bacmeister, J., Takacs, L., Liu, H.-C., Gu, W., Sienkiewicz, M., Koster, R., Gelaroa, R., Stajner, I., and Nielsen, J.: The GEOS-5 Data Assimilation System - Documentation of Versions 5.0.1, 5.1.0, and 5.2.0., 27, Technical Report Series on Global Modeling and Data Assimilation, NASA, Greenbelt, Maryland, 2008.

Roberts, G., Wooster, M. J., and Lagoudakis, E.: Annual and diurnal african biomass burning temporal dynamics, Biogeosciences, 6 , 849-866, doi:10.5194/bg-6-849-2009, 2009.

Ross, A. N., Wooster, M. J., Boesch, H., and Parker, R.: First satellite measurements of carbon dioxide and methane emission ratios in wildfire plumes, Geophys. Res. Lett., 40, 4098-4102, doi:10.1002/grl.50733, 2013.

Sessions, W. R., Fuelberg, H. E., Kahn, R. A., and Winker, D. M.: An investigation of methods for injecting emissions from boreal wildfires using WRF-Chem during ARCTAS, Atmos. Chem. Phys., 11, 5719-5744, doi:10.5194/acp-11-5719-2011, 2011.

Shephard, M. W. and Edward, J. K.: Effect of band-to-band coregistration on fire property retrievals, Trans. Geos. Rem. Sens., 11, 2648-2661, doi:10.1109/TGRS.2003.814912, 2003.

Sofiev, M., Ermakova, T., and Vankevich, R.: Evaluation of the smoke-injection height from wild-land fires using remote-sensing data, Atmos. Chem. Phys., 12, 1995-2006, doi:10.5194/acp-12-1995-2012, 2012. 
Streets, D. G., Zhang, Q., Wang, L., He, K., Hao, J., Wu, Y., Tang, Y., and Carmichael, G. R.: Revisiting China's CO emissions after the Transport and Chemical Evolution over the Pacific (TRACE-P) mission: Synthesis of inventories, atmospheric modeling, and observations, J. Geophys. Res., 111, D14306, doi:10.1029/2006JD007118, 2006.

Luderer, G., Trentmann, J., and Andreae, M. O.: A new look at the role of fire-released moisture on the dynamics of atmospheric pyro-convection, Int. J. Wildland Fire, 18, 554-562, 2009.

Trentmann, J., Luderer, G., Winterrath, T., Fromm, M. D., Servranckx, R., Textor, C., Herzog, M., Graf, H.-F., and Andreae, M. O.: Modeling of biomass smoke injection into the lower stratosphere by a large forest fire (Part I): reference simulation, Atmos. Chem. Phys., 6, 5247-5260, doi:10.5194/acp-65247-2006, 2006.

Val Martin, M., Logan, J. A., Kahn, R. A., Leung, F.-Y., Nelson, D. L., and Diner, D. J.: Smoke injection heights from fires in North America: analysis of 5 years of satellite observations, Atmos. Chem. Phys., 10, 1491-1510, doi:10.5194/acp-10-14912010, 2010

Val Martin, M., Kahn, R. A., Logan, J. A., Paugam, R., Wooster, M., and Ichoku, C.: Space-based observational constraints for 1D fire smoke plume-rise models, J. Geophys. Res., 117, D22204, doi:10.1029/2012JD018370, 2012.

van der Werf, G. R., Randerson, J. T., Giglio, L., Collatz, G. J., Kasibhatla, P. S., and Arellano Jr., A. F.: Interannual variability in global biomass burning emissions from 1997 to 2004, Atmos. Chem. Phys., 6, 3423-3441, doi:10.5194/acp-6-3423-2006, 2006.

van der Werf, G. R., Randerson, J. T., Giglio, L., Collatz, G. J., Mu, M., Kasibhatla, P. S., Morton, D. C., DeFries, R. S., Jin, Y., and van Leeuwen, T. T.: Global fire emissions and the contribution of deforestation, savanna, forest, agricultural, and peat fires (1997-2009), Atmos. Chem. Phys., 10, 11707-11735, doi:10.5194/acp-10-11707-2010, 2010.
Vermote, E., Ellicott, E., Dubovik, O., Lapyonok, T., Chin, M., Giglio, L., and Roberts, G. J.: An approach to estimate global biomass burning emissions of organic and black carbon from MODIS fire radiative power, J. Geophys. Res., 114, D18205, doi:10.1029/2008JD011188, 2009.

Wooster, M. J., Zhukov, B., and Oertel, D.: Fire radiative energy for quantitative study of biomass burning: derivation from the BIRD experimental satellite and comparison to MODIS fire products, Remote Sens. Environ., 86, 83-107, 2003.

Wooster, M. J., Roberts, G., and Perry, G. L. W.: Retrieval of biomass combustion rates and totals from fire radiative power observations: FRP derivation and calibration relationships between biomass consumption and fire radiative energy release, J. Geophys. Res., 110, D24311, doi:10.1029/2005JD006318, 2005.

Wooster, M., Xu, W., and Nightingale, T.: Sentinel-3 SLSTR active fire detection and FRP product: Pre-launch algorithm development and performance evaluation using MODIS and ASTER datasets, Remote Sens. Environ., 120, 236-254, 2012.

Yevich, R. and Logan, J. A.: An assessment of biofuel use and burning of agricultural waste in the developing world, Global Biogeochem. Cy., 17, 1095, doi:10.1029/2002GB001952, 2003.

Zhang, L., Li, Q. B., Jin, J., Liu, H., Livesey, N., Jiang, J. H., Mao, Y., Chen, D., Luo, M., and Chen, Y.: Impacts of 2006 Indonesian fires and dynamics on tropical upper tropospheric carbon monoxide and ozone, Atmos. Chem. Phys., 11, 1092910946, doi:10.5194/acp-11-10929-2011, 2011.

Zhukov, B., Lorenz, E., Oertel, D., Wooster, M., and Roberts, G.: Spaceborne detection and characterization of fires during the bispectral infrared detection (BIRD) experimental small satellite mission, Remote Sens. Environ., 100, 29-51, 2005. 